\title{
Restoration in a Changing Climate
}

I $\mathrm{t}$ gives me great pleasure to be writing this editorial for the first time as incoming Chair of the Society for Ecological Restoration International. I take over this responsibility at the end of SERI's biennial conference in Perth, Western Australia, in August, and I am deeply honored and humbled to serve the Society in this position. I am excited at the appointment of our new Executive Director, Amanda Jorgenson, who comes to us from the California Native Plant Society, who will be based in Washington DC, and who will be instrumental in continuing to implement the Society's strategic plan.

I have been involved in the Society since 1991 when I attended my first SER conference in Orlando, Florida, and was hooked by the purpose, excitement, and dedication of all those fellow travelers who are members, officers, and staff of the Society. I have been working in the field of restoration ecology, principally in mined lands, studying the soil microbial community in these systems, how it can inform us of the state of the ecosystem we are trying to restore and how it can be used to enhance the rate at which systems recover, and developing methodologies and applications for use by practitioners and regulators.

These are challenging times for us all, with the crisis in the world economy and the increasing pressures brought about by a burgeoning global population, land conversion, and global climate change. Recently, Professor John Beddington, the United Kingdom's Chief Scientist, has warned of a "perfect storm" approaching us by 2030 (McGourty 2009)—food shortages, scarce water, and insufficient energy resources threaten to result in public unrest, cross-border conflicts, and mass migration, as people flee from the worst-affected regions. There will also be increased pressure, particularly on Northern Hemisphere regions already facing agricultural intensification and unsustainable bioenergy crops, to intensify food production. There is no doubt that stark choices may be faced with trade-offs between biodiversity and food production, making advocacy for ecological restoration more difficult. We have to be clear that ecological restoration offers benefits across a wide range of ecosystem goods and services, including food

Ecological Restoration Vol. 27, No. 3, 2009

ISSN 1522-4740 E-ISSN 1543-4079

C2009 by the Board of Regents of the University of Wisconsin System. production, climate regulation, and most importantly building social capital - without which society cannot be sustained. We must provide clear evidence that this is the case and continue to press for ecological restoration as a central and important task for global society. There are hopeful signs that many governments and companies recognize this and are beginning to take an "ecosystems approach" to assessing and implementing development plans.

This, of course, is exactly what we are doing through the pages of Ecological Restoration and Restoration Ecology; meetings of members at chapter, regional, and international scales; the work of the Science and Policy Group, with its Briefing Notes and Policy Position Statements; and the engagement with such bodies as International Union for the Conservation of Nature and the Convention on Biological Diversity. Our involvement with the Canadian government in the production of the "Principles and Guidelines for Ecological Restoration in Canada's Protected Natural Areas" (National Parks Directorate 2009), widely recognized as an exemplar of such engagement, uses SERI documents, such as the Primer (SER 2002) and Guidelines and Standards (Clewell et al. 2005), as a starting point. The European Union has adopted the Environmental Liability Directive, which has explicit provisions to ensure that environmental damage is addressed by the restoration of ecosystems, and there are calls for an "ecosystem directive" to be considered. By putting ecological restoration at the heart of the way in which governments achieve environmental resilience and sustainability, we can achieve a major step forward for society as a whole. We need to emphasize to those we meet and work with at all levels that "it's the ecology, stupid."

None of this would be possible without the continuing dedicated work and support of the membership of the Society, who are involved at all of these scales, teaching, informing, influencing, and practicing ecological restoration in its widest sense, and the Society is dedicated to supporting you in these efforts.

I'd like to finish on a personal note regarding my predecessor and outgoing Chair (and therefore Vice-Chair), George Gann. George has been a tower of strength in the period when we were without an Executive Director, applying intelligence and common sense in equal measure (and a great deal of time and effort) to ensure 
the continued running of the Society. I know that I have been set a high bar to achieve and hope that I can continue to serve the Society in a dedicated and effective way, as George has.

Jim Harris

Chair

Society for Ecological Restoration International

\section{References}

Clewell, A., J. Rieger and J. Munro. 2005. Guidelines for Developing and Managing Ecological Restoration Projects, 2nd ed. Tucson AZ: Society for Ecological Restoration International. www.ser.org/ content/guidelines_ecological_restoration.asp

McGourty, C. 2009. Global crisis “to strike by 2010.” BBC News March 19. news.bbc.co.uk/2/hi/uk_news/7951838.stm

National Parks Directorate. 2009. Principles and Guidelines for Ecological Restoration in Canada's Protected Natural Areas. Gatineau, Quebec: Parks Canada Agency. www.pc.gc.ca/eng// docs/pc/guide/resteco/index.aspx

Society for Ecological Restoration International, Science and Policy Working Group (SER). 2002. The SER Primer for Ecological Restoration. Tucson AZ: Society for Ecological Restoration International. www.ser.org/content/ecological_restoration_ primer.asp 